\title{
The Difference of Digital Simulation Learning Outcomes In A Subject of Spreadsheet By Using Prezi, Adobe Premiere, and Microsoft Office Powerpoint
}

\author{
Suriaty ${ }^{1}$, Dewi Rosita ${ }^{2}$, Andi Rustandi ${ }^{3}$ \\ ${ }^{1,2,3}$ Dept. of Education of Computer Science, Faculty of Teacher Training and Education, Mulawarman University, Indonesia \\ suriaty@fkip.unmul.ac.id, dewi.rosita@fkip.unmul.ac.id, andi.rustandi@fkip.unmul.ac.id
}

\begin{abstract}
This is a quasi-experimental research. The research design was Posttest only control group design. The sampling technique in this study was purposive cluster sampling after 3 classes were chosen based on daily examination score on word processing application utilization subject, namely XI-3 Pharmacy class with Prezi media, XI-4 Pharmacy with Adobe Premiere media, and XI-1 Nursing class Microsoft Power Point media. In this lesson was given the subject of spreadsheet application. Data collection was the test of learning result of Digital Simulation in essay form. The data analysis in this study used one way anova test by using SPSS 17 program, which previously analyzed its normality with Kolmogorov-Smirnov One-Sample test with $\alpha=$ 0,05 for the three classes were learning by using Prezi media, learning by using Adobe Premiere, and using Microsoft PowerPoint successively obtained value $p>\alpha$ is $0.192 ; 0.184$; $0.200>0.05$ so that the three groups were normally distributed. Homogeneity test by using Levene's test obtained $p>\alpha$ value is $0.095>0,05$ means the three groups come from population with homogeneous variance. The result of data analysis using One Way Anova test with $\alpha=0,05$ obtained statistical value Fhitung $=$ 5,268 with $p=0,007$ then $p<\alpha$, so there was difference of learning result of Digital Simulation using Prezi media, Adobe Premiere media and Microsoft PowerPoint media. Further analysis used Tukey's HSD test seen that the learning media that have significant difference in learning using Adobe Premiere media and Microsoft Power Point media. From the results of the study can be concluded "There are differences in learning results on Digital Simulation in utilization of the spreadsheet application between the use of media of Prezi, Adobe Premiere, and Microsoft office PowerPoint on students class XI SMKN 17 Samarinda". Better learning outcomes are in Class XI-4 Pharmacy by using Adobe Premiere.
\end{abstract}

Keywords—prezi; adobe premiere; microsoft powerpoint; learning outcomes

\section{INTRODUCTION}

In terms of educational technology, media or materials as a learning resource is a component of the instructional system in addition to messages, people, background techniques and tools.
Learning media is one component that has an important role in learning. Utilization of media should be a part that should get the attention of teachers in every learning activity. According to $[1,2]$ media is a tool of communication channels.

The use of media or tools is based on many educational practitioners is very helpful in the learning process activities both inside and outside the classroom, especially help improve student achievement, but the implementation is not many teachers who use it, even the use of lecture method (monectonic method) is still quite popular among teachers in the learning process $[3,4]$.

In development, initially the media is only considered as a teaching aids teacher. The tools used are visual aids, such as drawings, models, objects and other tools that can provide concrete experience, learning motivation as well as enhance student absorption and retention, but due to over-focusing aspects of design, development of production learning and evaluation. The influx of audio technology in the mid-20th century. The visual tool for concocting this teaching is equipped with audio tools so that we are familiar with audio visual [5-7].

Students learning outcomes are determined by factors that can influence them. One factor from the outside is the availability of instructional media that can provide convenience for students to learn provided subjects in order to get better learning outcomes. Learning media has an important role to be able to support the learning process, because it can help teachers to explain the various information given to students effectively and efficiently. One of the media used by teachers in the classroom is the presentation tool.

\section{Methodology}

This research belongs to quasi-experimental research which is pseudo-experimental. The experimental research is conducted by giving a particular treatment to the subject of the research concerned by using the experimental design of The Posttest Control Group Design. 
The experimental group 1 was given the treatment of Prezi media, the experimental group 2 was Adobe Premier Media and in the control group was Microsoft PowerPoint. As explained in Table I. This research used purposive cluster sampling technique.

TABLE I. Postest CONTROL Group Design

\begin{tabular}{|c|c|c|}
\hline group & treatment & Posttest \\
\hline 1 & $\mathrm{X}_{1}$ & $\mathrm{Y}$ \\
\hline 2 & $\mathrm{X}_{2}$ & $\mathrm{Y}$ \\
\hline $\mathrm{CC}$ & $\mathrm{X}_{3}$ & $\mathrm{Y}$ \\
\hline
\end{tabular}

Explanation:

$\begin{array}{lll}1 & : \text { Experimental class of } 1 \\ 2 & : \text { Experimental class of } 2 \\ \mathrm{CC} & : \text { Controlled Class by using Microsoft } \\ & & \text { PowerPoint media. } \\ \mathrm{X}_{1} & : & \text { Treated with Prezi media } \\ \mathrm{X}_{2} & : & \text { Treated with Adobe Premiere } \\ & \text { media } \\ \mathrm{X}_{3} & : \text { Treated with Microsoft PowerPoint } \\ \mathrm{Y} & : \text { Examined Learning Outcomes } \\ & & \text { (Posttest) in instructional media. }\end{array}$

The research variables consist of three independent variables and one dependent variable. The independent variable are instructional media, consisting of Prezi, Adobe Premiere, and Microsoft PowerPoint. The dependents variable is learning outcomes of digital simulation. The population in this study are students of class XI SMK Negeri 17 Samarinda. The sample in this research are 3 classes, they are XI-1 Pharmacy class of 34 students, XI-3 Pharmacy class of 34 students, and XI-4 Pharmacy class 34 students, Table II. The sampling technique used is Purposive Cluster Sampling, by choosing a grade that has an average score not significantly different in the sample determination. The Experiment and Control group was selected based on the documentation of the students' daily examination score of the previous subject, it was word processing application.

TABLE II. RECORD OF SCORES OF CLASS XI

\begin{tabular}{|c|c|c|}
\hline No & Class & Mean \\
\hline 1 & XI-1 pharmacy & 73,47 \\
\hline 2 & XI-1 pharmacy & 78,24 \\
\hline 3 & XI-1 pharmacy & 77,76 \\
\hline
\end{tabular}

The data collection used documentationa and test.

\section{1) Documentation}

Preliminary data on academic ability is derived from daily test scores on the previous material i.e. the utilization of word processing applications. The examination outcomes of word processing is an early ability, and used for the formation of groups in learning that will take place in class.

\section{2) Test}

The test is used to obtain the learning score of Digital Simulation about learning media using Prezi, Adobe Premiere, and Microsoft PowerPoint in experimental class or taught by using Microsoft PowerPoint in control class. The test used is essay. Before the problem is used in the experimental and control class it is first tested for difficulty index, differentiation index, and reliability of the question [8].

Techniques Data analysis using descriptive statistics and inferential statistics. Descriptive statistics are used to describe or analyze a statistical research result, but are not used to make wider conclusions. Inferential statistics using normality test, homogeneity test, and anova test. One Way Anova Test is done to know whether there is difference of two or more treatments, where the independent variable is Prezi learning media, Adobe Premiere learning media, and Microsoft PowerPoint learning media, while the dependent variable is the result of digital student simulation learning. Prior to the first Anova One Direction test data were first tested normally or not with normality test, and tested population data with homogeneous variation by homogeneity test of variance [4].

\section{RESULTS AND DISCUSSION}

This study uses 3 classes as a sample, 2 classes as experimental class that is XI-3 Pharmacy class with learning using Prezi media and XI-4 Pharmacy class with learning using Adobe Premiere media, while XI-1 Pharmacy class become control class by using Microsoft Power point. After the experimental class 1 by using Prezi learning media, experiment class 2 using Adobe Premiere learning media, and control class using Microsoft PowerPoint learning media. All three groups were given a Digital Simulation learning test to measure their learning outcomes. Before the problem is tested on the class that becomes the research sample, first tested in another class that is class XI-2 Pharmacy. After the data is collected, the next step is analyzed using descriptive statistics and inferential statistics.

Table II shows that descriptive statistics of research results of Digital Simulation learning test for experimental class 1 by using Prezi learning media, second experiment class by using Adobe Premiere learning media, and control class with learning media Microsoft PowerPoint.

TABLE III. DESCRIPTION OF STUDENT Digital SimUlation LEARNING DATA OUTCOMES

\begin{tabular}{|c|c|c|c|c|}
\hline Media & mean & Top scores & $\begin{array}{c}\text { Lower } \\
\text { scores }\end{array}$ & $\begin{array}{c}\text { standard } \\
\text { deviation }\end{array}$ \\
\hline Prezi & 85,94 & 97 & 60 & 9,400 \\
\hline $\begin{array}{c}\text { Adobe } \\
\text { Premiere }\end{array}$ & 90,03 & 99 & 78 & 6,078 \\
\hline $\begin{array}{c}\text { Microsoft } \\
\text { Power-Point. }\end{array}$ & 83,62 & 97 & 60 & 8,873 \\
\hline
\end{tabular}

Table III shown that the mean for the experimental class that used the learning media of Prezi with the number of students of 34 is 85.94 with standard deviation 9,400 , the highest scorer is 97 and the lowest is 60 . The average score by using Adobe Premiere's learning media with 34 students is 90.03 with standard deviation of 6,078 , the highest score is 99 and the lowest is 78, while the mean with Microsoft PowerPoint learning media with 34 students is 83.62 with the 
standard deviation of 8,873 , the highest score is 97 and the lowest is 60 . From the descriptive statistics showing that the learning outcomes of the three classes used, the average of the final test scores for the experimental class is higher than the control class.

Data analysis using inferential statistics of Digital Simulation learning test data and calculation using SPSS 17 program can be explained as follows:

Test of data normality, test of normality of test data of learning result of Digital Simulation with Kolmogorov Smirnov One-Sample test and calculation by using program of SPSS $17, \mathrm{H} 0$ accepted if value $\mathrm{p}>\alpha$, with hypothesis:

- $\mathrm{H} 0$ is received if Dmax $\leq$ Dtable or $\mathrm{p}>\alpha$, then the data is normally distributed.

- H0 is accepted if $\mathrm{p}>\alpha$, with $\alpha=0.05 \mathrm{H} 0$ is rejected if $\mathrm{p}$ $<\alpha$, with $\alpha=0.05$.

The data of digital learning test result of Digital Simulation obtained probability for experimental group using Prezi learning media is 0,192 , probability value for experiment group by using Adobe Premiere learning media is 0,184, and probability value for group using Microsoft PowerPoint learning media is 0,200 . Testing level used is $\alpha=0,05$ and $p>\alpha$ value for all three groups are not enough evidence to reject $\mathrm{H} 0$, so it can be concluded data value of test result of learning of Digital Simulation for three group of normal distribution.

\section{1) Data homogeneity test,}

Homogeneity test of test result data using Levene's test. The statistical hypothesis of the Levene's test is:

$$
\begin{aligned}
& \mathrm{H}_{0:} \sigma 1^{2}=\sigma 2^{2}=\sigma 3^{2} \\
& \mathrm{H}_{0}: \sigma_{\mathrm{i}}^{2} \neq \sigma_{\mathrm{j}}^{2}, \mathrm{i}=1,2,3, \mathrm{j}=1,2,3
\end{aligned}
$$

To test the similarity of variance in this study also used Levene's test where the test results indicate that the learning result of Digital Simulation has significant value 0.095 . Because the value with a significant level $\alpha=0.05$, so $0.095>$ $0.05(p>\alpha)$ then there is not enough evidence to reject H0. It can be concluded that the Digital Simulation learning test results data for the three classes of the population with homogeneous variance.

\section{2) Test the mean difference.}

The test data of the learning result of Digital Simulation is normally distributed with homogeneous variance. The hypothesis is formulated as follows:

$$
\begin{aligned}
& \text { H0: } \mu 1=\mu 2=\mu 3 \\
& \text { H } \alpha: \mu i \neq \mu \mathrm{j}, \mathrm{i}=\mathrm{j}=1,2,3
\end{aligned}
$$

TABLE IV. TABLE OF ONE WAY ANOVA CALCULATION

\begin{tabular}{|l|c|c|c|c|c|}
\hline $\begin{array}{l}\text { Variance } \\
\text { Resource }\end{array}$ & $\mathrm{Db}$ & $\mathrm{JK}$ & $\mathrm{KT}$ & F_Count & $\begin{array}{c}\text { F_Table } \\
5 \%\end{array}$ \\
\hline Behavior & 2 & 716,529 & 358,265 & 5,268 & 2,88 \\
\hline Error & 99 & 6732,882 & 68,009 & - & - \\
\hline Total & 101 & 744,412 & - & - & - \\
\hline
\end{tabular}

Based on the Table IV, obtained value Fcount $\doteq 5.268$ and Ftable $=2.88$ which means Fcount $>$ Ftable, then Ho is rejected. It can be concluded that there are differences in learning outcomes between students using Prezi learning media, Adobe Premiere learning media, and Microsoft PowerPoint learning media.

3) Using Tukey's HSD test :

- The statistically significant level $=0.107$. Significant level of testing $\alpha=0.05$. Because of $0.107>0.05$, so the mean of the experimental class with Prezi learning media does not have a real difference with the experimental class with the learning media Adobe Premiere.

- The statistically significant level $=0.479$ Significant level of testing $\alpha=0.05$. Because of $0.479>0.05$, so the mean of the experimental class with Prezi learning media has no real difference with the control class with the Microsoft PowerPoint learning medium.

- The statistically significant level $=0.005$. Significant level of testing $\alpha=0.05$. Because of $0.005<0.05$, so the mean of the experimental class with Adobe Premiere learning media has a real difference with the control class with Microsoft PowerPoint learning media.

TABLE V. PARTS OF TUKEY'S HSD TYPE

\begin{tabular}{|c|c|c|c|}
\hline \multirow{2}{*}{ Class } & \multirow{2}{*}{$\mathrm{N}$} & \multicolumn{2}{|c|}{ Subset for alpha $=0.05$} \\
\cline { 3 - 4 } & & 1 & 2 \\
\hline Microsoft PowerPoint & 34 & 83,62 & \\
\hline Prezi & 34 & 85,94 & 85,94 \\
\hline Adobe Premiere & 34 & & 90,03 \\
\hline Sig & &, 479 &, 107 \\
\hline
\end{tabular}

Table V, learning that has the same realistic averages is grouped into one. Can be seen from the three lessons are grouped into two parts, as follows:

- In section 1 was participated XI-1 Pharmacy and XI-3 Pharmacy class by using Microsoft PowerPoint and Prezi media with average 83.62 and 86.24 respectively.

- In section 2 was participated XI-3 Pharmacy and XI-4 Pharmacy class by using Prezi and Adobe Premiere media with an average of 86.24 and 90.03 respectively.

- In the XI-1 Pharmacy and XI-4 Pharmacy classes using Microsoft PowerPoint and Adobe Premiere media have differences with the respective averages of 83.62 and 90.03 , respectively.

Based on the discussion that there is a difference between learning by using Prezi learning media, Adobe Premiere learning media, and Microsoft PowerPoint learning media. Learning using Prezi learning media is not different from Adobe Premiere learning media. Learning by using Prezi learning media is not different from Microsoft PowerPoint learning media. And learning and learning using Adobe Premiere learning media is different from Microsoft PowerPoint learning. 


\section{CONCLUSION}

Based on the results of research and discussion it can be concluded that the differences in learning results Digital Simulation materials utilization of the number processing application using Prezi and Adobe Premiere. Then, there is a difference in learning outcomes Digital Simulation material utilization of number processing application by using Prezi and Microsoft PowerPoint. Later, differences in learning results Digital Simulation materials utilization of number processing application using Adobe Premiere and Microsoft PowerPoint. Latest, better Learning Results by using Adobe Premiere.

\section{REFERENCES}

[1] V. Joke and K. Gerald. (2008). International Handbook of Information Technology in Primary and Secondary Education.

[2] S. Joseph and M. Uther, "Mobile devices for language learning: Multimedia approach," Research and Practice in Technology Enhanced Learning, vol. 4, pp. 7-32, 2009 .
[3] I. J. Dunn, E. Heinxle, B. Dettwiler, U. Saner, G. Ryhiner, and J. Ingham, "Application of Digital Simulation Languages with Personal Computers in Chemical and Biochemical Engineering Education," Chemical Engineering Science, vol. 43 No. 8, pp. 1897-1902, 1988.

[4] L. P. Macfadyen, "Overcoming Barriers to Educational Analytics: How Systems Thinking and Pragmatism Can Help," Educational Technology, vol. v57 n1 Jan-Feb 2017, pp. 31-39, 2017.

[5] S. K. W. Chu, R. B. Reynolds, N. J. Tavares, M. Notari, and C. W. Y. Lee, "Twenty-First Century Skills Education in Switzerland: An Example of Project-Based Learning Using Wiki in Science Education," 2017.

[6] M. M. Luis, C. R. Jose, and G. C. Mercè, "Pre-service Physical Education Teachers' self-management ability: a training experience in 3D simulation environments," Federación Española de Asociaciones de Docentes de Educación Física (FEADEF), vol. 32, pp. 30-34, 2017.

[7] K. Ciampa, "Reading in the digital age: using electronic books as a teaching tool for beginning readers," Canadian Journal of Learning and Technology, vol. 38, pp. 1-26, 2012.

[8] G. L. Gropper, "Instructional Design: Science, Technology, Both, Neither," Educational Technology, vol. 57 n1, pp. 40-52, 2017. 